\title{
Serum IgE level in relapsing idiopathic nephrotic syndrome in children
}

\begin{abstract}
Background: Nephrotic syndrome patient have altered serum IgE level during acute attack and remission.. An increase in the serum $\operatorname{IgE}$ may be a reflection of body immuno regulatory imbalance that play direct pathogenic role in the occurrence of NS and proteinuria.

Methods: The aim of this cross sectional comparative study was to assess the level of serum IgE level in relapse of nephrotic syndrome and to see the difference of serum IgE level between infrequent relapse and frequent relapse carried out in the Department of Pediatric Nephrology, Comilla Medical College Hospital during the time from July 2015 to December 2015. A total of 60 subjects were recruited, consisting of 30 of relapse NS was enrolled as a cases and 30 of initial attack NS same age group was enrolled as controls. Serum IgE level was estimated by IMMULITE2000 Reader before starting therapy with prednisolone. The mean serum IgE level of cases and of controls was estimated respectively. Statistical difference between serum IgE level of cases and control was seen by unpaired t test.
\end{abstract}

Results: The mean serum IgE level of relapse nephrotic syndrome in children was $(537.98 \pm 52.56 \mathrm{IU} / \mathrm{ml})$ which was higher than $\operatorname{control}(\mathrm{p}<0.05)$. The mean serum IgE level of infrequent relapse and frequent relapse were $860.00 \pm 50.00 \mathrm{IU} / \mathrm{mL}$ and $1441.00 \pm 95.00 \mathrm{IU} / \mathrm{mL}$ respectively $(\mathrm{p}<0.05)$

Conclusion: With this study we reaffirm that serum IgE is high in relapse nephrotic syndrome and it is persistently and significantly higher in frequent relapsing group.
Volume 7 Issue 2 - 2019

\author{
Md Azizul Hossain,' Md Amjad Hossain, ${ }^{2}$ Kazi \\ Abdul Mannan, ${ }^{3}$ Kiriti Prosad Deb ${ }^{4}$ \\ 'Associate Professor and Head, Department of Pediatric \\ Nephrology, Comilla Medical College, Bangladesh \\ ${ }^{2}$ Assistant Registrar, Department of Pediatric Nephrology, \\ Comilla Medical College Hospital. \\ 3Professor \& Head, Department of Pediatrics, Comilla Medical \\ College, Bangladesh \\ ${ }^{4}$ Assistant Professor, Department of Pediatric Nephrology, \\ Comilla Medical College, Bangladesh
}

\begin{abstract}
Correspondence: Md Azizul Hossain,Associate Professor and Head, Department of Pediatric Nephrology, Comilla Medical College, Bangladesh, Tel +880 I7IIIII 299
\end{abstract}

Email tasbiul@yahoo.com

Received: May 15, 2018 | Published: April 02, 2019

\section{Introduction}

Nephrotic syndrome is a pathological entity characterized by massive proteinuria and hypoalbuminemia. Nephrotic range proteinuria is defined as proteinuria exceeding $1000 \mathrm{mg} / \mathrm{m}^{2} /$ day or spot urinary protein to creatinine ratio exceeding 2 . The protienuria in childhood nephrotic syndrome is relatively selective, constitute primarily by albumin. ${ }^{1}$ Estimate on the annual incidence of nephritic syndrome range from 2-7 per 100000 children and prevalence ${ }^{2}$ from 12-16 per 100000. There is epidemiological evidence of a higher incidence of nephritic syndrome in children from Asia. ${ }^{3}$ The condition is primary in 95 percent cases. An underlying disorder that might be identified in less than 5 percent cases, includes systemic lupus erythematosus, Henoch Schonlein Purpura, amyloidosis and infection with HIV, parvovirus B19 and hepatitis B and C. ${ }^{4,5}$ More than 80 percent patients with nephrotic syndrome show minimal change disease (MCD) characterized by normal histology on light microscopy. The remaining is contributed by focal segmental glumerulosclerosis (FSGS) and mesengioproliferative glumerulonephritis (MesPGN). MCD and FSGS are often considered to represent the same pathophysiological process. Membranous nephropathy and membranoproliferative conditions are uncommon in children. ${ }^{6-8}$ About $90 \%$ children with MCNS responds promptly to corticosteroid therapy with complete clinical and biochemical remission and have excellent long term prognosis. Among who responds to prednisolone, $20-40 \%$ have infrequent relapse and $40 \%$ have frequent relapse and reminder are steroid dependence. ${ }^{9}$ Relapse can be defined as the reappearance of massive proteinuria for 3 consecutive days after having gone into remission on previous occasion. ${ }^{9}$ Relapse can be of two types i.e. infrequent and frequent. Infrequent relapse can be defined as 3 or $<3$ relapses in any consecutive months, ${ }^{6}$ and frequent relapse can be defined as 4 or $>4$ relapses in any 12 months. ${ }^{10}$ Altered levels of different serum immuno globulins (Ig) during active NS and during remission have been documented by a number of studies. ${ }^{11-14}$ Blood contains three types of globulins; alpha, beta and gamma, based on their electrophoretic migration rates. Antibodies are gamma globulins. There are five classes of antibodies namely $\operatorname{IgG}, \operatorname{IgM}, \operatorname{IgA}, \operatorname{IgD}$ and $\mathrm{IgE}$. Among them IgG are reduced in NS. On the other hand serum $\operatorname{IgM}$ and $\operatorname{IgE}$ are raised while serum $\operatorname{IgA}$ are within normal limits when the patients are in active disease. ${ }^{15} \mathrm{IgE}$ is medically important for two reasons; it mediates immediate (anaphylactic) hypersensitivity reactions and it participates in host defenses against certain parasites. Persons with allergic reactivity have greatly increased amount and IgE may appear in external secretion. The cause of MCNS remains unclear, although several immunologic mechanisms have postulated. Relapses of disease have been reported in association with seasonal allergics ${ }^{16,17}$ or atopic disease ${ }^{18}$ and others have noted elevated serum IgE concentration in children with MCNS..$^{15,19,20}$ In a study conducted in China have shown that during the acute nephrotic syndrome, the serum IgE level in MCNS were significantly elevated, these high serum IgE levels decreased in remission of NS and elevated again during relapse. An increase in the serum $\operatorname{IgE}$ may be a reflection of body immunoregulatory imbalance that play direct pathogenic role in the occurrence of NS and proteinuria. ${ }^{21}$ Nephrotic syndrome encompasses morbidity as well as mortality of children. Relapse NS carries a higher mortality and morbidity due to frequent association with severe complications. This morbidity due to complications of relapse of NS should be prevented and this deserves a scientific study to find out different issues related to relapse of NS. Serum IgE level may have association with relapsing NS. The goal of this study was to identify the relationship between serum IgE level and relapse of NS to be used as a diagnostic, prognostic and predictor indicator of relapsing NS. 


\section{Materials and methods}

The aim of this cross sectional comparative study was to assess the level of serum IgE level in relapse of nephrotic syndrome and to see the difference of serum IgE level between infrequent relapse and frequent relapse carried out in the Department of Pediatric Nephrology, Comilla Medical College Hospital during the time from July 2015 to December 2015. Study population was all nephrotic syndrome patient aging from 1 year to 10 years irrespective of sex with some inclusion and exclusion criteria. A total of 30 cases and 30 suitably matched controls were enrolled in the study by simple random sampling. Relapses patient was selected as cases and age and sex matched initial attack NS was selected as controls. Before starting therapy with prednisolone serum IgE level of both case and control were measured by highly sensitive analyzer (IMMULITE2000 Elisa Reader). Data was collected by a preformed structured questionnaire. Data was processed, calculated and analyzed using computer software. Un pair $t$ test was done to compare the mean difference between serum $\operatorname{IgE}$ level in cases and in controls. The statistical analysis was performed using the Statistical Package for Social Service (SPSS) version 16.0 for Windows.

\section{Results}

Among 30 cases and 30 controls $53.33 \%$ children were male and $46.66 \%$ were female. Maximum children were male. Male and female ratio in cases and controls was 1.14:1 (Tables 1-7). Table 2 shows the difference of serum IgE level between case and controls. According to unpaired $t$ test, critical value (p-value 0.05 ) of $\mathrm{t}$ on $\mathrm{t}$ distribution table is 1.671 which is less than $t$ calculated value (7.42). Table-IV shows mean serum IgE was higher in age group 7-10 years than in age group 2-6 years in both cases and controls, $p$ value $<0.05$. Table 6 shows the mean serum IgE level in frequent relapse $(144 \pm 95 \mathrm{IU} / \mathrm{mL})$ was higher than NS children with infrequent relapse $(860 \pm 50)$, $\mathrm{p}$ value $<0.05$. Table 7 shows mean serum IgE was higher in age group 7-10 years than in age group 2-6 years in both frequent relapse (cases) and infrequent relapse (controls), $\mathrm{p}$ value $<0.05$.

Table I Age distribution of cases and controls

$\begin{array}{llll}\text { Characteristics } & \begin{array}{l}\text { Cases } \\ (\mathbf{n = 3 0 )} \mathbf{n}(\%)\end{array} & \begin{array}{l}\text { Controls } \\ (\mathbf{n}=30) \mathbf{n}(\%)\end{array} & \text { p value* } \\ \text { Age } & 22(73.0) & 22(73.0) & >0.05 \\ \circ \text { 2- } 6 \text { years } & 08(27.0) & 08(27.0) & \\ \circ \text { 7-10 years } & & \end{array}$

*Chi square test was done to measure the level of significance.

Table 2 Sex distribution of cases and controls

\begin{tabular}{llll}
\hline Characteristics & $\begin{array}{l}\text { Case }(\mathbf{n = 3 0 )} \\
\mathbf{n}(\%)\end{array}$ & $\begin{array}{l}\text { Controls } \\
(\mathbf{n = 3 0 )} \mathbf{n}(\%)\end{array}$ & p value* \\
\hline Sex & & & \\
\hline$\circ$ Male & $16(53.33)$ & $16(53.33)$ & $>0.05$ \\
$\circ$ Female & $14(46.66)$ & $14(46.66)$ & \\
\hline
\end{tabular}

*Chi square test was done to measure the level of significance.

\section{Discussion}

The nephrotic syndrome was more common in the age group 2 to 6 years. $73 \%$ of initial attack NS, infrequent relapse NS and frequent relapse NS patients were present within this age group which is consistent with other previous report. ${ }^{22-25}$ Mean age in the age group $2-6$ years of cases and controls was $4.7 \pm 1.5$ and $4.5 \pm 1.5$ respectively which was statistically not significant $(\mathrm{p}>0.05)$ and is consistent with previous data ${ }^{23,24}$ where study subjects were age matched. In nephrotic syndrome boys are more commonly affected than girls. Out of 60 children, 32 were males and 28 were female patients. Male and female ratio in cases and controls was 1.14: 1 which was consistent with previous data. ${ }^{9,23,24,25}$ Study subjects were found to be more common in males, so cases and controls were also sex matched. Mean blood urea and serum creatinine levels was observed statistically not significant $(p>0.05)$ in initial attack and relapsing NS and is similar with prior findings. ${ }^{4,13,35}$ Mean serum total protein, spot urinary protein creatinine ratio and 24 hours urinary total protein was also observed statistically not significant $(\mathrm{p}>0.05)$ in initial attack and relapsing NS and is in harmony other outcomes., ${ }^{4,1026}$ Mean serum cholesterol level in relapsing NS was observed to be significantly higher $(401 \pm 42 \mathrm{mg} / \mathrm{dl})$ than that in initial attack $(310 \pm 42 \mathrm{mg} / \mathrm{dl})$, again mean serum cholesterol level in frequent relapse NS was also observed to be significantly higher $(462 \pm 42 \mathrm{mg} / \mathrm{dl})$ than that in infrequent relapse NS $(340 \pm 42 \mathrm{mg} /$ $\mathrm{dl}$ ), which was statistically significant ( $\mathrm{p}$ value $<0.05$ ) and is coherent with other outcomes. ${ }^{4,26}$ Serum IgE is increased with age. Mean serum IgE level in age group 7-10 years both case and control was observed to be significantly $(\mathrm{p}<0.05)$ higher than that in age group 2 to 6 years (Table-IV and VI) which was statistically significant ( $\mathrm{p}$ value $<0.05$ ) and is in harmony with other results. ${ }^{15,27-35}$ Mean serum IgE level (Table 3 ) in cases was observed to be significantly $(p<0.001)$ higher than controls and this is consistent with other studies. ${ }^{12,24}$ Mean serum IgE level (Table-IV) of frequent relapse was significantly $(p<0.05)$ higher than that infrequent relapse which was statistically significant and is similar with previous studies. ${ }^{17,19}$ High serum IgE level during the period of relapse and remission can be considered to be a predictor of frequent relapse.

Table 3 Baseline characteristics of cases and controls

\begin{tabular}{|c|c|c|c|}
\hline \multirow{3}{*}{ Parameters } & \multicolumn{3}{|l|}{ Groups } \\
\hline & Cases $(n=30)$ & Controls $(n=30)$ & p value* \\
\hline & Mean士SD & Mean士SD & \\
\hline Age: $2-6$ years $(n=22)$ & $4.70 \pm 1.50$ & $4.50 \pm 1.50$ & $>0.05$ \\
\hline Age: 7 - I0years $(n=08)$ & $7.70 \pm 1.80$ & $7.40 \pm 1.50$ & $>0.05$ \\
\hline $\begin{array}{l}\text { Serum total } \\
\text { protein }(g m / L)\end{array}$ & $50.30 \pm 0.83$ & $48.97 \pm 1.11$ & 0.362 \\
\hline $\begin{array}{l}\text { Serum albumin in gm/ } \\
\text { dl }( \pm S D)\end{array}$ & I. $37 \pm 0.59$ & $1.57 \pm 0.67$ & $0.038 \mathrm{~S}$ \\
\hline $\begin{array}{l}\text { Serum cholesterol in } \\
\mathrm{mg} / \mathrm{dl}( \pm \mathrm{SD})\end{array}$ & $401.00 \pm 42.00$ & $310.00 \pm 42.00$ & $0.040 \mathrm{~S}$ \\
\hline Spot UPCR & $10.43 \pm 1.42$ & $8.82 \pm 0.96$ & 0.564 \\
\hline $\begin{array}{l}24 \text { hours urinary total } \\
\text { protein }\end{array}$ & $3.20 \pm 0.34$ & $2.93 \pm 0.11$ & 0.427 \\
\hline $\begin{array}{l}\text { TCE count }(0-400 / \\
\mathrm{cmm})\end{array}$ & $401.00 \pm 42.00$ & $350.00 \pm 42.00$ & 0.263 \\
\hline Blood urea $(\mathrm{mmol} / \mathrm{L})$ & $5.24 \pm 1.35$ & $4.50 \pm 0.45$ & 0.801 \\
\hline $\begin{array}{l}\text { Serum } \\
\text { creatinine(mmol/L) }\end{array}$ & $76.57 \pm 2.73$ & $75.38 \pm 2.05$ & 0.946 \\
\hline $\begin{array}{l}\text { Urine pus cell }(<5 / \\
\text { HPF) }\end{array}$ & $5.00 \pm 1.00$ & $4.00 \pm 1.00$ & 0.97 \\
\hline
\end{tabular}

*Unpaired $t$ test was done to measure the level of significance. 
Table 4 Difference of Serum IgE level between cases and controls

\begin{tabular}{llllll}
\hline $\begin{array}{l}\text { Nephrotic } \\
\text { syndrome }\end{array}$ & Mean & \pm SD & t & df & p value* \\
\hline Cases $(n=30)$ & 1150.7 & \pm 74.61 & 7.42 & 58 & $<0.001$ \\
Controls $(n=30)$ & 537.98 & \pm 52.56 & & &
\end{tabular}

*Unpaired $\mathrm{t}$ test was done to measure the level of significance.

Table 5 Comparison of serum lgE level between cases and controls in different age groups

\begin{tabular}{llll}
\hline \multicolumn{2}{l}{ Age (years) group } & P value* \\
\cline { 1 - 3 } & 2- $6(\mathbf{n}=22)$ & 7-10 (n=08) & \\
\cline { 2 - 3 } & Mean \pm SD & Mean \pm SD & \\
\hline Cases $(n=30)$ & $1110.50 \pm 52.00$ & $1261.32 \pm 64.00$ & $<0.05^{5}$ \\
Controls $(n=30)$ & $510.98 \pm 52.00$ & $612.23 \pm 52.00$ & $<0.05^{\mathrm{s}}$ \\
\hline
\end{tabular}

*Unpaired $\mathrm{t}$ test was done to measure the level of significance

Table 6 Comparison of serum lgE level between Frequent Relapse and Infrequent Relapse NS

\begin{tabular}{|c|c|c|c|}
\hline & Groups & & p value* \\
\hline & Frequent Relapse & $\begin{array}{l}\text { Infrequent } \\
\text { Relapse }\end{array}$ & \\
\hline & $(n=15)$ & $(n=15)$ & \\
\hline & Mean $\pm S D$ & Mean $\pm S D$ & \\
\hline $\begin{array}{l}\text { \#Serum IgE in } \\
\text { Relapse (IU/mL) }\end{array}$ & $|44| .00 \pm 95.00$ & $860.00 \pm 50.00$ & $<0.05^{\mathrm{s}}$ \\
\hline
\end{tabular}

*Unpaired $\mathrm{t}$ test was done to measure the level of significance.

Table 7 Comparison of serum IgE level between Frequent Relapse and Infrequent Relapse NS in different age groups

\begin{tabular}{|c|c|c|c|}
\hline & $\begin{array}{l}\text { Age (years) } \\
\text { group }\end{array}$ & & p value* \\
\hline & $2-6(n=I I)$ & $7-10(n=04)$ & \\
\hline & Mean $\pm S D$ & Mean $\pm S D$ & \\
\hline $\begin{array}{l}\text { Frequent Relapse } \\
(n=15)\end{array}$ & $1402.00 \pm 69.00$ & $1548.00 \pm 72.00$ & $<0.05^{s}$ \\
\hline $\begin{array}{l}\text { Infrequent Relapse } \\
(\mathrm{n}=15)\end{array}$ & $840.00 \pm 50.00$ & $915.00 \pm 50.00$ & $<0.05^{s}$ \\
\hline
\end{tabular}

*Unpaired $t$ test was done to measure the level of significance.

\section{Conclusion}

With this study we reaffirm that serum IgE is high in relapse nephrotic syndrome and it is persistently and significantly higher in frequent relapsing group.

\section{Recommendation}

This finding suggests that IgE may play an important role in the pathogenesis of MCNS and level of the serum IgE can be used as a prognostic and predictor indicator and thus we shall prevent and alert subsequent complications as well as morbidity of relapse nephrotic syndrome. Further studies including large sample size is recommended.

\section{Acknowledgments}

None.

\section{Conflicts of interest}

Authors declare no conflict of interest.

\section{References}

1. Arabinda Bagga, Mukta Mantan. Nephrotic syndrome in children. Indian J Med Res. 2005; 122:13-15.

2. Eddy AA, Symons JM. Nephrotic syndrome in childhood Lancet.2003;362(9384):629-639.

3. Mc Kenny PA, Feltbower RG, Brocklebank JT, et al. Time trends and ethnic patterns of childhood nephritic syndrome in Yorkshire, UK. Pediatric Nephrol. 2001;16(12):1040-1044.

4. Bagga A, Srivasta RN. Nephrotic Syndrome. In: Srivasta, et al. editors. Pediatric Nephrology 6th ed. New Delhi; Jaypee; 2016.191-233 p.

5. Moudigil A, Nast CC, Bagga A, et al. Association of parvovirus B19 infection with idiopathic collapsing glumerolopathy. Kidney Int. 2001;59(6):2126-2133.

6. Churg J, Habib R, White RH. Pathology of the nephritic syndrome in children. A report for the international Study of Kidney Disease in Children. Lancet. 1970;760(1):1299-302.

7. White RH, Glasgow EF, Mills RJ, Clinicopathological study of nephritic syndrome in childhood. Lancet. 1970:1(7661);1353-1359.

8. Srivasta RN, Mayekar G, Anand R, et al. Nephrotic syndrome in Indian children. Arch Dish Child. 1975;50(8):625-630.

9. Nanjundaswamy HM. Phadke KD. Steroid Sensative Nephrotic Syndrome. Indian J Pediatr. 2002;69(12):1059-1063.

10. Pryia Pais, Ellis D Avnar. Nephrotic syndrome. In: Kliegman, Stanton ST, et al. editors. Nelsion Textbook of Pediatrics. 19th ed. South East Asia Edition; Saunders; 2012. 1801-07 p.

11. Tain YL, Yi Chen T, Yang KD. Implication of serum IgE in childhood nephrotic syndrome. Pediatr Nepheol. 2003;1211-1215.

12. Mansfield LE, Trygstad CW, Ajugwo RE, et al. Serum concentration of immunoglobulin E and alpha2- macroglobulin in childhood renal disease. J Allergy Clin Immunol. 1980;66(3):227-232.

13. Yap HK, Yip WC, Lee BW, et al. The incidence of atopy in steroid responsive nephrotic syndrome- clinical and immunological parameters. Ann Allergy. 1983;51(6):590-594.

14. Florida JF, Diaz PJM, Belchi J, et al. Nephrotic syndrome and respiratory allergy in childhood. $J$ investing Allergol Clin Immunol. 1992;2(3):136-140.

15. Meadow SR, Sarsfield JK, Scott DG, et al. Steroid responsive nephrotic syndrome and allergy- immunological study. Arch Dis Child. 1981;56(7):517-524.

16. Zeis PM, Kavazarakis E, Nakopoulou L, et al. Glomerulopathy with mesangial IgM deposits: Long $\square$ term follow up of 64 children. Pediatr Int. 2001;43(3):287-292.

17. Mary GB, Geoffrey SN, Michael JB et al. Immunoglobulin synthesis by peripheral blood mononuclear cells in minimal change nephrotic syndrome. Kidney Int.1983;23(2):380-386.

18. Pansky B. Urinary and Excretory system. Review of Medical Embryology. New York: Mc Millian, 1982;244-248.

19. Andal A, Chellani H, Anand NK, et al. Low serum immunoglobulin G-a predictor of frequent relapse in idiopathic nephrotic syndrome. Indian pediatr.1990;27(10):1045-1049.

20. Chan MK, Chan KW, Jones B. Immunoglobulins (IgG, IgA, IgM, $\mathrm{IgE})$ and compliment components $(\mathrm{C} 3, \mathrm{C} 4)$ in nephrotic syndrome due to minimal change and other firms of glomerulonephritis- a clue for steroid therapy. Nephron.1987;47(2):125-130.

21. Lin CY, Lee BH, Lin CC, et al. A study of relationship between childhood nephrotic syndrome and allergy. Chest.1990;97(6):1408-1411. 
22. Lewis MA, Baildom EM, Davis N, et al. Nephrotic Syndrome. From toddlers to twenties. Lancet. 1989;1(8632):255-259.

23. Bagga A, Srivastava RN. Nephrotic Syndrome and Proteinuria. Indian J Pediatr. 2002;69(12):1053-1058.

24. Banerjee S. Steroid Resistant Nephrotic Syndrome. The Indian Journal of Pediatrics. 2002;69(12):1065-1069.

25. Pryia Pais, Ellis D Avnar. Nephrotic syndrome. In: Kliegman, editors Nelsion Textbook of Pediatrics. 20th ed. South East Asia Edition; Saunders; 2016. 2521-27 p.

26. Bagga, Ali U, Benerjee S, et al. Management of Steriod Sensitive Nephrotic Syndrome: Revised guideline. Indian Pediatric Nephrology Group, Indian Academy of Pediatrics; Indian Pediatr. 2008;45:203214.

27. Levinson MHW, Jawetz E. Medical Microbiology \& Immunology Examination and Board review. 6th Ed, Newyork; 2000. 363-373 p.

28. Ahmed ZU, Zaman CB. Steroid responsiveness in nephrotic syndrome: A three year prospective study. Bang AF Med J. 1992;16(1):43-45.
29. International study of Kidney disease in children. Early identification of frequent relapses among children with minimal change nephrotic syndrome. J Pediatr.1982;101:514-518.

30. Patrick Niaudet. Steroid sensitive idiopathic nephrotic syndrome in children. In: Ellis D Avner, et al, editors. Pediatric Nephrology, 7th Edition; 2016. 839-882 p.

31. Tenbrock K, Schubert ASL, Kemper MJ, et al. Type 1 IgE receptor, interleukin 4 receptor and interleukin 13 polymorphism in children with nephrotic syndrome. Clin Sci (Lond). 2002;102(5):507-512.

32. Meadow SR, Sarsfield JK. Steroid responsive nephrotic syndrome and allergy- Clinical studies. Arch Dis Child. 1981;56(7):509-516.

33. Robson-WL, Leung-Ak. Nephrotic syndrome in childhood. AdvPediatr 1993;40:287-323.

34. International study of kidney disease in children. Nephrotic syndrome in children, prediction of histopathology from clinical and laboratory characteristic at time of diagnosis. Kidney Int.1978;13(2):159-65.

35. A Takeda, H Matsutani, F Niimura, et al. Risk factors for relapse in childhood nephrotic syndrome. Pediatr Nephrol.1996;10(6):740-741. 